\title{
ASSOCIATION OF IFN- $\gamma$ AND P2X7 RECEPTOR GENE POLYMORPHISMS IN SUSCEPTIBILITY TO TUBERCULOSIS AMONG IRANIAN PATIENTS
}

\author{
MAHdi SHAMSI ${ }^{1}$, MOHAMMAd ReZA ZOLFAGHARI ${ }^{2 *}$, PARISSA FARNIA ${ }^{1}$ \\ ${ }^{1}$ Mycobacteriology Research Centre, National Research Institute \\ of Tuberculosis and Lung Disease, Masih Daneshvari Hospital, \\ Shahid Beheshti University of Medical Sciences, Tehran, Iran. \\ ${ }^{2}$ Department of Microbiology, Qom Branch, Islamic Azad University, Qom, Iran.
}

(Received: 13 October 2015; accepted: 5 February 2016)

\begin{abstract}
Interferon-gamma (IFN- $\gamma$ ) and P2X7 receptor are crucial for host defence against mycobacterial infections. Recent studies have indicated that IFN- $\gamma$, IFN- $\gamma$ receptor 1 (IFN- $\gamma \mathrm{R} 1)$ and $2 \mathrm{X} 7$ gene polymorphisms are associated with susceptibility to pulmonary tuberculosis (TB). However, the relationship between IFN- $\gamma$ and P2X7 polymorphism and TB susceptibility remains inconclusive in Iranian population. For this reason, single nucleotide polymorphisms (SNPs) in IFN- $\gamma(\mathrm{G}+2109 \mathrm{~A})$, IFN- $\gamma$ R1 (G-611A) and P2X7 genes (at $-762,1513$ position) in patients $(n=100)$ were assessed using PCR-RFLP. Data were analysed with SPSS version 18. For the 2109 loci of IFN- $\gamma$ gene, the frequency of mutant alleles between patients and controls were not statistically significant. However, there was a significant difference between the TB patient and controls for -611 alleles of IFN- $\gamma R 1(P=0.01)$. Additionally, the frequency of P2X7 gene polymorphisms (SNP-762 and 1513) between patients and controls was statistically significant. In conclusions, our study revealed a significant association of IFN- $\gamma \mathrm{R} 1$ and $\mathrm{P} 2 \mathrm{X} 7$ genes polymorphisms with risk of developing TB in Iranian population.
\end{abstract}

Keywords: tuberculosis, IFN- $\gamma$, IFN- $\gamma$ R1, P2X7, polymorphisms, Iran

\section{Introduction}

Tuberculosis (TB) caused by Mycobacterium tuberculosis (MTB) remains a major public health problem in the world. According to the latest report released by world health organization (WHO), approximately one-third of the world's population is infected with MTB, with an estimated 9.6 million new cases [1].

\footnotetext{
*Corresponding author; E-mail: mreza.zolfaghary@gmail.com
} 
Among those who are infected, only 5-10\% will develop the active form of the disease with clinical symptoms [1]. Other infected individuals may remain noninfectious and symptoms free for many years. Factors that control progression of disease are still poorly defined for the majority of cases reported. Genetic variability and some environmental factors are expected to contribute to the risk of developing active tuberculosis [2, 3]. Genetic variations such as polymorphisms in the genes encoding interferon-gamma (IFN- $\gamma$ ), P2X7 receptor, interleukin-12, and vitamin D3 receptor, which occur more commonly, are considered to account for the susceptibility of the general population to TB [4-6]. IFN- $\gamma$ is a key $\mathrm{T}$ helper type 1 cytokine produced by natural killer cells and T cells [7]. Its production plays a pivotal role in macrophage activation for controlling mycobacterial infection [8]. Many studies have also shown that extracellular ATP, through the activation of the $\mathrm{P} 2 \mathrm{X} 7$ purinergic receptor, induces bactericidal activity of macrophages [9, 10]. Recently, IFN- $\gamma$ and P2X7 polymorphisms have been reported to be associated with pulmonary TB $[7,11]$. For example, IFN- $\gamma$ $(-2109 \mathrm{~A} / \mathrm{G})$ polymorphism was significantly associated with pulmonary TB in Croatian and Chinese populations $[12,13]$. In addition, P2X7 polymorphisms have been associated with TB in Gambian Population [11]. However, the association of IFN- $\gamma$ and P2X7 gene polymorphisms and pulmonary TB is somewhat controversial in Iranian population. The aim of this study was to investigate the correlation of polymorphisms in IFN- $\gamma(+2109 \mathrm{~A})$, IFN- $\gamma$ receptor-1 $(-611 \mathrm{~A})$ and P2X7 genes (-762 and 1513) in Iranian pulmonary TB patients.

\section{Materials and Methods}

\section{Setting and study population}

The study was conducted from January 2013 to December 2014, in the Mycobacteriology Research Center, Tehran, Iran. A total of 100 patients with culture-positive TB and 100 healthy volunteers (normal controls) were included in the study. The mean age of the patients and controls was 49 and 43 years, respectively. The male-to-female sex ratio was 1:2 (male/female: 33/67), with a similar distribution in both groups. The institutional review board at the center approved the study and all the patients have signed informed consent. 


\section{DNA extraction}

Genomic DNA was extracted using the standard protocol with minor modifications [14]. Briefly, peripheral blood leukocytes (PBLs) were separated from two millilitres of the whole blood using RBC lysis buffer $(0.155 \mathrm{M} \mathrm{NH} 4 \mathrm{Cl}$, $0.01 \mathrm{M}$ NaHCO3). Thereafter, PBLs were re-suspended in $500 \mu \mathrm{L}$ of SE buffer $(\mathrm{NaCl} 3 \mathrm{M}$, EDTA $0.5 \mathrm{M}, \mathrm{PH}=8$ ), containing $40 \mu \mathrm{L}$ of $10 \%$ SDS and $3 \mu \mathrm{L}$ of 20 $\mathrm{mg} / \mathrm{mL}$ of proteinase $\mathrm{K}$. The suspension was incubated at $60^{\circ} \mathrm{C}$ for 30 minutes. After incubation, $200 \mu \mathrm{L}$ of equilibrated phenol $(\mathrm{PH}=8)$ was added to the mixture and centrifuged for 10 minutes at $12000 \mathrm{~g}$. The aqueous phase was transferred to a new tube and the DNA was precipitated using cold propanol.

\section{IFN- $\gamma$ genotyping}

Single-nucleotide polymorphisms (SNPs) in IFN- $\gamma$ receptor-1 (G-611A), IFN- $\gamma(\mathrm{G}+2109 \mathrm{~A})$ were performed using PCR-RFLP. The target DNA was amplified in a PCR reaction mixture containing $1 \times$ reaction buffer $(50 \mathrm{mM} \mathrm{KCl}$, $67 \mathrm{mM}$ Tris- $\mathrm{HCl}$ [pH 9.0], $2 \mathrm{mM} \mathrm{MgCl}_{2}$ ), $2 \mathrm{mM}$ of dNTPs, $0.2 \mathrm{U}$ of Taq DNApolymerase (Roch, Germany), and 20 pmol of each primers. For IFN- $\gamma$ receptor-1G-611A, the following primers were used to amplify a 85 bp product: $5^{\prime}$ AGACAAACCCAGAGAGGTAAGAGA 3'; 5' ACCTTCTCAGCAATTCAGTGTCAAA 3'. For IFN- $\gamma(\mathrm{G}+2109 \mathrm{~A})$ polymorphisms, the following primers were used to amplify a 366 bp product; 5' AATCGCTGAAGTATGTAAT 3'; 5' GCATTGTAGAGTTTTG 3'. The PCR products of IFN- $\gamma$ receptor-1 and IFN- $\gamma$ were digested with 2 U enzymes of NIaIII and FauI, respectively. Digested products were run on $8 \%$ polyacrylamide gel and were stained with silver nitrate.

\section{P2X7 genotyping}

Polymorphisms in the P2X7 gene, namely P2X7 SNP-762 and 1513 were studied using PCR-RFLP. For P2X7 gene polymorphisms at $-762 \mathrm{C} / \mathrm{T}$ allele, two outer primers (P2X73 [5'-GAAACAGGGCCCTGGGTCCTC-3', forward] and P2X74 [5'-TGGTGGGGGTGGAGGGGC-3', reverse]) and two inner primers (P2X75 [5'-GGTGTCCCTCACTGAATAGGTCAAT-3', forward and P2X76 [5'-GGCAGTCCAACAAAGTTAGGTTTG-3', reverse]) were used. The amplification was accomplished by an initial denaturation at $94{ }^{\circ} \mathrm{C}$ for 5 minutes and 30 cycles at $95{ }^{\circ} \mathrm{C}$ for 30 seconds, at $65^{\circ} \mathrm{C}$ for 30 seconds, at $72{ }^{\circ} \mathrm{C}$ for 45 seconds, followed by an extension at $72{ }^{\circ} \mathrm{C}$ for 10 minutes. The amplified PCR 
products for CC, CT and TT had the following sizes 235 bp, 186+235 bp and $186 \mathrm{bp}$, respectively. For P2X7 gene polymorphisms at 1513, the primers $5^{\prime}$ ACTCCTAGATCCAGGGATAGCC 3' and 5' TACAGACGTGAGCCACGGT 3' were used to amplify the 417 bp product. The PCR product was digested with 4 $\mathrm{U}$ enzyme of Hae II. The digested PCR products were run on $8 \%$ polyacrylamide gel, which was stained with ethidium bromide. The digest pattern for AA, AC and CC are as follows; $209+143+65$ bp; $209+143+117+92+65$ bp and $143+117+$ $95+65$ bp, respectively.

\section{Statistical analysis}

The frequency of the genotypes in patients and control groups were estimated by direct gene counting and then the data was analysed using SPSS version 18 (SPSS Inc., Chicago, IL, USA). The odds ratio and p values were calculated for each allele in patient and control groups. All p values were two tailed. A $\mathrm{p}$ value of less than $<0.05$ was considered significant with $95 \%$ confidence interval (CI).

\section{Results}

Genotype and allele frequencies for IFN- $\gamma$ gene polymorphisms

The results of genotyping for the patients with Pulmonary TB and controls are presented in Table I. At the IFN- $\gamma-2109 \mathrm{~A} / \mathrm{G}$ polymorphic site, patient and control groups had a very similar distribution; about $85 \%$ of the A and about $15 \%$ of the $\mathrm{G}$ type. Genotype frequency analysis in patients showed that the largest group was comprised of/A homozygotes (66\%). The A/G heterozygous group followed (31.0\%), and the G/G homozygotes were rare (3\%). A significant difference in the allele frequency distribution between patients and controls was not observed ( $p$ value $>0.05$ ).

A comparison of the IFN- $\gamma \mathrm{R} 1-611 \mathrm{~A} / \mathrm{G}$ polymorphisms in patients and controls is also summarized in Table I. Based on the statistical analysis, there were statistically significant differences, in genotypic frequencies, of IFN- $\gamma$ R1 polymorphismsbetween patients and controls ( $\mathrm{p}$ value $<0.05$ ).

Genotype and allele frequencies for P2X7 gene polymorphisms

The frequency of the $1513 \mathrm{~A}$ allele in the TB patients was $66.0 \%$, whereas that of $1513 \mathrm{C}$ was $34.0 \%$, and a significant differences were noted in compari- 
Table I. Frequency of the IFNR1-611 and IFN-2109 polymorphisms in the Iranian population

\begin{tabular}{lccc}
\hline Genes & Control $(\mathrm{n}=100)$ & Patients $(\mathrm{n}=100)$ & P value \\
\hline IFNRI-611 & & & \\
Genotype & & & \\
AA (\%) & $55(55.0)$ & $74(74.0)$ & 0.01 \\
AG (\%) & $34(34.0)$ & $22(22.0)$ & \\
GG (\%) & $11(11.0)$ & $4(4.0)$ & \\
\hline Allele & & & \\
A (\%) & $144(72.0)$ & $170(85.0)$ & \\
G (\%) & $56(28.0)$ & $30(15.0)$ & \\
\hline IFN-2109 & & & \\
Genotype & $70(70.0)$ & $66(66.0)$ & \\
AA (\%) & $30(30.0)$ & $31(31.0)$ & \\
AG (\%) & $0(0.0)$ & $3(3.0)$ & 0.25 \\
GG (\%) & $170(85.0)$ & $163(81.5)$ & \\
\hline Allele & $30(15.0)$ & $37(18.5)$ & \\
A (\%) & &
\end{tabular}

Table II. Frequency of the -762 and -1513 polymorphisms of $\mathrm{P} 2 \mathrm{X} 7$ in the Iranian population

\begin{tabular}{lccc}
\hline Genes & Control $(\mathrm{n}=100)$ & Patients $(\mathrm{n}=100)$ & P value \\
\hline P2X7-762 & & & \\
Genotype & & & \\
TT (\%) & $1(1.0)$ & $0(0.0)$ & 0.00 \\
TC (\%) & $93(93.0)$ & $99(99.0)$ & \\
CC (\%) & $6(6.0)$ & $1(1.0)$ & \\
\hline Allele & & & \\
T (\%) & $95(47.5)$ & $99(85.0)$ & \\
C (\%) & $105(52.5)$ & $101(15.0)$ & \\
\hline P2X7-1513 & & & 0.00 \\
Genotype & $83(83.0)$ & $33(33.0)$ & \\
AA (\%) & $16(16.0)$ & $66(66.0)$ & \\
AC (\%) & $1(1.0)$ & $1(1.0)$ & 0.00 \\
CC (\%) & $182(91.0)$ & $132(66.0)$ & \\
\hline Allele & $18(9.0)$ & $68(34.0)$ & \\
A (\%) & & \\
C (\%) & &
\end{tabular}

son with the frequencies in the case of the control subjects (Table II). The heterozygosity $(\mathrm{A} / \mathrm{C})$ was higher in patients $(66.0 \%)$ than controls: $(16.0 \%)$ and the difference was statistically significant $(\mathrm{P}=0.00)$.

For the -762 loci, $99.0 \%$ of patients had heterozygote mutant alleles (T/C variants) and $1.0 \%$ had infrequent homozygote alleles $(\mathrm{C} / \mathrm{C})$. No individual car- 
ried the wild type (T/T) at -762 in the patients group. In general, as presented in Table II, the frequency of P2X7 gene polymorphisms between patients and controls was statistically significant ( $p$ value $<0.05$ ).

\section{Discussion}

Our study was performed to determine whether known polymorphisms of the IFN- $\gamma$, IFN- $\gamma \mathrm{R} 1$ and $\mathrm{P} 2 \mathrm{X} 7$ gene were correlated with susceptibility to TB disease in the Iranian population.

IFN- $\gamma$ is the key cytokine involved in the protective response against mycobacterial infection [15]. Interferon gamma by binding with the receptor complex (IFN- $\gamma$ R1) results in cellular activation. In different experimental analysis, TB patients had deficient IFN- $\gamma$ production in their peripheral blood mononuclear cells [14]. In addition, it has been shown that partial or complete loss of function alleles of IFN- $\gamma / \mathrm{IFN}-\gamma \mathrm{R} 1$ genes associated with various mycobacterial infections $[16,17]$. In the present study, we have failed to show an association between IFN- $\gamma-2109 \mathrm{~A} / \mathrm{G}$ polymorphisms and TB disease in a sample of the Iranian population (Table I). However, IFN- $\gamma$ R1-611 A/G SNP allele was significantly associated with increased susceptibility to TB. On the contrary to our results, Varahram et al, did not find any significant association between IFN- $\gamma$ R1-611 SNP and susceptibility to TB among Iranian studied cases [14]. Also, few studies declines the correlation of IFN- $\gamma \mathrm{R} 1$ polymorphism with M. tuberculosis infection [18, 19]. At present, we have no explanation for such discrepancy, but these observations may outline the alternative pathways for enhancing host immune response against mycobacterial infections.

In present investigations, we also found two polymorphisms of $\mathrm{P} 2 \mathrm{X} 7$ gene (-762 and -1513] that were significantly associated with TB patients (Table II). For P2X7-762 T/C SNP, T allele was more frequent in TB cases as compared to control. Previously, Bahari et al., also find a positive association between P2X7-762 T/C SNP and susceptibility to TB among Iranian cases [20]. Similarly, subsequent investigation reported nearly the same observations; during 20112012, Singla et al. showed a positive correlation between TB and the $-762 \mathrm{C}$ allele [21]. However, in their analysis, only males showed a significant association between P2X7-762 T/C and TB. Our results were also similar to those observed in Indian populations, and are supported by a recent meta-analysis reporting subjects with the $\mathrm{C}$ allele at higher risk of developing TB $[22,23]$.

The P2X7-762 promoter polymorphism falls in the region where several transcription factors tend to bind [11]. Thus, sequence changes in this region may affect the activity of $\mathrm{P} 2 \mathrm{X} 7$ receptor expression and alters its ability to regulate 
macrophage activity which helps in controlling TB infection [22]. Additional to 762 polymorphism, $1513 \mathrm{~T}$ to $\mathrm{C}$ allele frequency in the $\mathrm{P} 2 \mathrm{X} 7$ gene were also investigated. We found a higher frequency of $1513 \mathrm{C}$ allele in patients $(34 \%)$ than control (9\%) subject. Therefore, a higher risk of developing TB in individuals with hetero or homozygous allele of 1513 was highlighted. Some studies reported the importance of the $1513 \mathrm{C}$ allele with pulmonary TB [24, 25]. However, the mechanisms by which these genotypes can protect the pathogenicity of TB have not been completely explained.

In conclusion, our study revealed a significant association of IFN- $\gamma \mathrm{R} 1$ and P2X7 genes polymorphisms with TB patients in Iranian population. But, no positive association was found between frequencies of IFN- $\gamma$ SNPs in host and development of TB. As the genetic control of the immune response in TB seems to be polygenic, it is likely that the study of other cytokines or genes will improve our understanding of the mechanism of such a complex disease.

\section{Acknowledgement}

The study was supported by National Research Institute of Tuberculosis and Lung Disease, Tehran, Iran.

\section{Conflict of Interest}

The authors declare that there is no conflict of interests regarding the publication of this paper.

\section{References}

1. World health Organization: Global tuberculosis report 2015. Geneva: World Health Organization; 2015. Available from URL: http://www.who.int/tb/publications/global_ report/ en/

2. Cooke, G. S., Hill, A. V.: Genetics of susceptibitlity to human infectious disease. Nat Rev Genet 2, 967-977 (2001).

3. Azad, A. K., Sadee, W., Schlesinger, L. S.: Innate immune gene polymorphisms in tuberculosis. Infect Immun IAI 443-412 (2012).

4. Döffinger, R., Dupuis, S., Picard, C., Fieschi, C., Feinberg, J., Barcenas-Morales, G., Casanova, J.-L.: Inherited disorders of IL-12- and IFN $\gamma$-mediated immunity: a molecular genetics update. Mol Immunol 38, 903-909 (2002).

5. Bellamy, R.: Susceptibility to mycobacterial infections: the importance of host genetics. Genes Immun 4, 4-11 (2003). 
6. Cao, Y., Wang, X., Cao, Z., Cheng, X.: Association of vitamin D receptor gene TaqI polymorphisms with tuberculosis susceptibility: a meta-analysis. Int J Clin Exp Med 8, 10187-10203 (2015).

7. López-Maderuelo, D., Arnalich, F., Serantes, R., Gonzalez, A., Codoceo, R., Madero, R., Vázquez, J. J., Montiel, C.: Interferon- $\gamma$ and interleukin-10 gene polymorphisms in pulmonary tuberculosis. Am J Respir Crit Care Med 167, 970-975 (2003).

8. Flynn, J. L., Ernst, J. D.: Immune responses in tuberculosis. Curr Opin Immunol 12, 432-436 (2000).

9. Fairbairn, I. P., Stober, C. B., Kumararatne, D. S., Lammas, D. A.: ATP-mediated killing of intracellular mycobacteria by macrophages is a $\mathrm{P} 2 \mathrm{X} 7$-dependent process inducing bacterial death by phagosome-lysosome fusion. J Immunol 167, 3300-3307 (2001).

10. Fuller, S. J., Stokes, L., Skarratt, K. K., Gu, B. J., Wiley, J. S.: Genetics of the P2X7 receptor and human disease. Purinergic Signal 5, 257-262 (2009).

11. Li, C. M., Campbell, S. J., Kumararatne, D. S., Bellamy, R., Ruwende, C., McAdam, K. P., Hill, A. V., Lammas, D. A.: Association of a polymorphism in the P2X7 gene with tuberculosis in a Gambian population. J Infect Dis 186, 1458-1462 (2002).

12. Etokebe, G., Bulat-Kardum, L., Johansen, M., Knezevic, J., Balen, S., Matakovic-Mileusnic, N., Matanic, D., Flego, V., Pavelic, J., Beg-Zec, Z.: Interferon- $\gamma$ gene (T874A and G2109A) polymorphisms are associated with microscopy-positive tuberculosis. Scand J Immunol 63, 136-141 (2006).

13. Yang, Y., Li, X., Cui, W., Guan, L., Shen, F., Xu, J., Zhou, F., Li, M., Gao, C., Jin, Q.: Potential association of pulmonary tuberculosis with genetic polymorphisms of Toll-like receptor 9 and interferon-gamma in a Chinese population. BMC Infect Dis 13, 511-522 (2013).

14. Varahram, M., Farnia, P., Nasiri, M. J., Karahrudi, M. A., Dizagie, M. K., Velayati, A. A.: Association of Mycobacterium tuberculosis lineages with IFN- $\gamma$ and TNF- $\alpha$ gene polymorphisms among pulmonary tuberculosis patient. Mediterr J Hematol Infect Dis 6, e2014015 (2014).

15. Flynn, J. L., Chan, J.: Immunology of tuberculosis. Annu Rev Immunol 19, 93-129 (2001).

16. Guide, S. V., Holland, S. M.: Host susceptibility factors in mycobacterial infection: genetics and body morphotype. Infect Dis Clin North Am 16, 163-186 (2002).

17. Dorman, S. E., Picard, C., Lammas, D., Heyne, K., van Dissel, J. T., Baretto, R., Rosenzweig, S. D., Newport, M., Levin, M., Roesler, J.: Clinical features of dominant and recessive interferon $\gamma$ receptor 1 deficiencies. The Lancet 364, 2113-2121 (2004).

18. Mirsaeidi, S., Houshmand, M., Tabarsi, P., Banoei, M., Zargari, L., Amiri, M., Mansouri, S., Sanati, M., Masjedi, M.: Lack of association between interferon-gamma receptor-1 polymorphism and pulmonary TB in Iranian population sample. J Infect 52, 374-377 (2006).

19. Awomoyi, A., Nejentsev, S., Richardson, A., Hull, J., Koch, O., Podinovskaia, M., Todd, J., McAdam, K., Blackwell, J., Kwiatkowski, D.: No association between interferon- $\gamma$ receptor-1 gene polymorphism and pulmonary tuberculosis in a Gambian population sample. Thorax 59, 291-294 (2004).

20. Bahari, G., Hashemi, M., Taheri, M., Naderi, M., Moazeni-Roodi, A., Kouhpayeh, H., Eskandari-Nasab, E.: Association of P 2 X 7 gene polymorphisms with susceptibility to pulmonary tuberculosis in Zahedan: Southeast Iran. Genet Mol Res 12, 160-166 (2013). 
21. Singla, N., Gupta, D., Joshi, A., Batra, N., Singh, J.: Genetic polymorphisms in the P2X7 gene and its association with susceptibility to tuberculosis. Int J Tuberc Lung Dis 16, 224-229 (2012).

22. Sambasivan, V., Murthy, K. J. R., Reddy, R., Vijayalakshimi, V., Hasan, Q.: P2X7 gene polymorphisms and risk assessment for pulmonary tuberculosis in Asian Indians. Dis Markers 28, 43-48 (2010).

23. Xiao, J., Sun, L., Yan, H., Jiao, W., Miao, Q., Feng, W., Wu, X., Gu, Y., Jiao, A., Guo, Y.: Metaanalysis of P2X7 gene polymorphisms and tuberculosis susceptibility. FEMS Immunology \& Medical Microbiology 60, 165-170 (2010).

24. Niño-Moreno, P., Portales-Pérez, D., Hernández-Castro, B., Portales-Cervantes, L., Flores-Meraz, V., Baranda, L., Gómez-Gómez, A., Acuña-Alonzo, V., Granados, J., González-Amaro, R.: P2X7 and NRAMP1/SLC11 A1 gene polymorphisms in Mexican mestizo patients with pulmonary tuberculosis. Clin Exp Immunol 148, 469-477 (2007).

25. Mokrousov, I., Sapozhnikova, N., Narvskaya, O.: Mycobacterium tuberculosis co-existence with humans: making an imprint on the macrophage P2X7 receptor gene. J Med Microbiol 57, 581-584 (2008). 